\title{
ІНФОРМАЦІЙНІ ТА МІКРОЕЛЕКТРОННІ ТЕХНОЛОГІЇ ДЛЯ ЗАСТОСУВАННЯ В МОБІЛЬНІЙ МЕДИЦИНІ. НАДІЇ ТА ОБМЕЖЕННЯ
}

\author{
О. П. Мінцер, В. А. Романов ${ }^{1}$, \\ І. Б. Галелюка ${ }^{1}$, А. В. Антонова ${ }^{1}$ \\ Національна медична академія післядипломної освіти імені П. Л. Шупика \\ ${ }^{1}$ /нститут кібернетики імені В. М. Глушкова НАН України
}

\begin{abstract}
Розглянуто питання використання в медичній практиці інсрормаційних і мікроелектронних технологій. Підкреслюється думка про необхідність врахування для діагностики патологічного процесу даних передісторії захворювання й узагальнення відомостей про попередні та паралельні дослідження пацієнта в інших закладах охорони здоров'я робить малоперспективним широке застосування подібних пристроїв у практичній медицині. Зроблено висновки про те, що сорера їх використання в мобільній медицині обмежена практичними випадками, які не вимагають детального знання та передісторії патологічного процесу. Підкреслюється також, що на нинішньому етапі розвитку медицини істотне розширення напрямів застосування мікроелектронної техніки може бути забезпечено шляхом спільного її використання зі штучним інтелектом.
\end{abstract}

Ключові слова: інформаційні технології, мікроелектронні технології, мобільна медицина, персоналізована медицина, моніторинг стану пацієнта, портативні медичні сенсорні прилади, комунікатори, ідентифікація та інтерпретація медичної інфрормації, агрегування медичних даних, штучний інтелект.

\section{INFORMATION AND MICROELECTRONIC TECHNOLOGIES FOR APPLICATION IN MOBILE MEDICINE. HOPES AND LIMITATIONS}

\author{
O. P. Mintser, V. A. Romanov' ${ }^{1}$, \\ I. B. Galelyuka ${ }^{1}$, A. V. Antonova ${ }^{1}$ \\ Shupyk National Medical Academy of Postgraduate Education \\ ${ }^{1} \mathrm{~V}$. M. Glushkov Institute of Cybernetics of NAS of Ukraine
}

\begin{abstract}
The issues of using information and microelectronic technologies in medical practice are considered. It is emphasized that the need to take into account the history of the disease for the diagnosis of the pathological process and the aggregation of information about the patient's previous and parallel studies in other medical institutions makes the widespread use of such devices in practical medicine unsuccessful. Conclusions are drawn about the scope of their use in mobile medicine limited to practical cases that do not require detailed knowledge and background of the pathological process. It is also emphasized that at the present stage of the development of medicine, a significant expansion of the directions of the use of microelectronic technology can be ensured by its joint use with artificial intelligence.
\end{abstract}

Key words: information technologies, microelectronic technologies, mobile medicine, personalized medicine, patient monitoring, portable medical sensory devices, communicators, identification and interpretation of medical information, aggregation of medical data, artificial intelligence. 


\title{
ИНФОРМАЦИОННЫЕ И МИКРОЭЛЕКТРОННЫЕ ТЕХНОЛОГИИ ДЛЯ ПРИМЕНЕНИЯ В МОБИЛЬНОЙ МЕДИЦИНЕ. НАДЕЖДЫ И ОГРАНИЧЕНИЯ
}

\author{
О. П. Минцер, В. А. Романов ${ }^{1}$, \\ И. Б. Галелюка ${ }^{1}$, А. В. Антонова ${ }^{1}$ \\ Национальная медицинская академия последипломного образования имени П. Л. Шупика \\ ${ }^{1}$ Институт кибернетики имени В. М. Глушкова НАН Украины
}

\begin{abstract}
Рассмотрены вопросы использования в медицинской практике информационных и микроэлектронных технологий. Подчеркивается мысль о необходимости учета для диагностики патологического процесса данных предыстории заболевания и агрегирование сведений о предшествующих и параллельных исследованиях пациента в других учреждениях здравоохранения делает малоперспективным широкое применение подобных устройств в практической медицине. Сделаны выводы о том, что сфера их использования в мобильной медицине ограничена практическими случаями, которые не требуют детального знания и предыстории патологического процесса. Подчеркивается также, что на нынешнем этапе развития медицины существенное расширение направлений применения микроэлектронной техники может быть обеспечено путем совместного ее использования с искусственным интеллектом.
\end{abstract}

Ключевые слова: информационные технологии, микроэлектронные технологии, мобильная медицина, персонализированная медицина, мониторинг состояния пациента, портативные медицинские сенсорные приборы, коммуникаторы, идентификация и интерпретация медицинской инорормации, агрегирование медицинских данных, искусственный интеллект.

Вступ. У клінічних умовах застосування мікроелектроніки здійснюється виключно швидкими темпами. Неврологічні стимулятори, моніторинг лікувальних заходів при лікуванні пухлин, кардіологія та пульмонологія — це лише деякі з захоплюючих областей, де використовуються пристрої. Протягом наступного десятиліття нові системи допоможуть людям із такими захворюваннями, як хвороба Паркінсона, розсіяний склероз, психічні розлади.

Зовні схожий процес відбувається й в амбулаторній практиці. Крім того, останніми роками різко прискорилося старіння населення, збільшилася кількість хронічних хворих, зросла вартість медичних послуг. Ця тенденція збережеться й в найближчі роки, і до 2030 року відповідно до прогнозів третина населення земної кулі буде старше 65 років, причому 40 \% із них потребуватимуть постійної медичної допомоги, насамперед при використанні принципів мобільної медицини. Без цієї допомоги незалежне існування таких пацієнтів буде проблематичним.

Важливо підкреслити, що лікування пацієнтів стає індивідуалізованим. Відходять у минуле стандарти надання медичної допомоги, що стають інструментом лише оцінювання планованих фінансових витрат на потреби охорони здоров'я.

Персоналізація та постійний моніторинг стану пацієнтів визначають їх нову «середу існування», що характеризується постійним відстеженням стану пацієнта, його кількісного оцінювання, прогнозуванням значень життєво важливих фізіологічних параметрів. У такому середовищі люди похилого віку, які страждають хронічними хворобами, перебуватимуть досить тривалий час.

Характерною рисою нинішнього періоду розвитку мікроелектронних технологій $€$ те, що в завданнях конструювання нових приладів 3'являються не тільки завдання моніторингу, але й прийняття рішень щодо лікування. Так, завершено роботу над штучною підшлунковою залозою, що демонструє успіхи в боротьбі з цукровим діабетом 1-го типу. Система використовує електрохімічний датчик, що визначає рівні глюкози кожні 5 хвилин. Якщо виявлений високий рівень глюкози, то автоматично вводиться інсулін; якщо виявлено низький рівеньглікоген [16].

Розвиток інформаційних технологій і мікроелектроніки на сучасному етапі дозволяє створювати принципово нові монітори здоров'я, зробити їх доступними для широких верств населення. Однак труднощі та непереборні перешкоди для широкого поширення залишаються.

Мета дослідження: аналіз і узагальнення відомостей щодо використання в медичній практиці інформаційних і мікроелектронних технологій.

Результати та їх обговорення. Формальні погляди на моніторинг стану пацієнтів. Для вимірювання фізіологічних параметрів пацієнта й оцінювання його стану, в одяг можуть бути вбудовані різні медичні сенсори, такі як сенсор частоти пульсу, сенсор частоти дихання, сенсор температури тіла, фотоплетизмограф, сенсори кардіосигналів і тиску, акселерометр тощо. Їх застосуванню присвячена значна кількість робіт [4, 9, 11, 13, 17-19, 20]. 

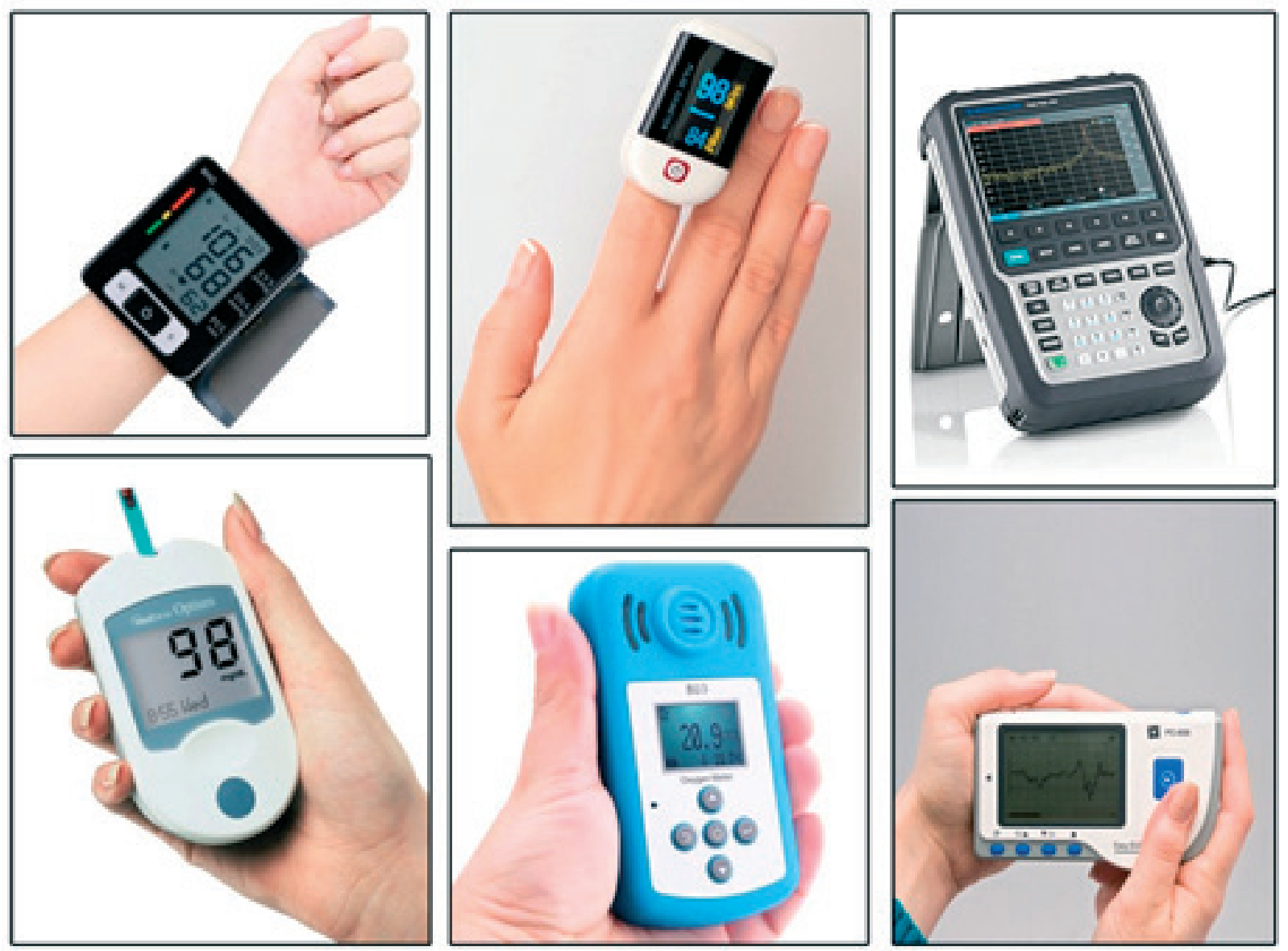

Рис. 1. Приклади портативних медичних приладів

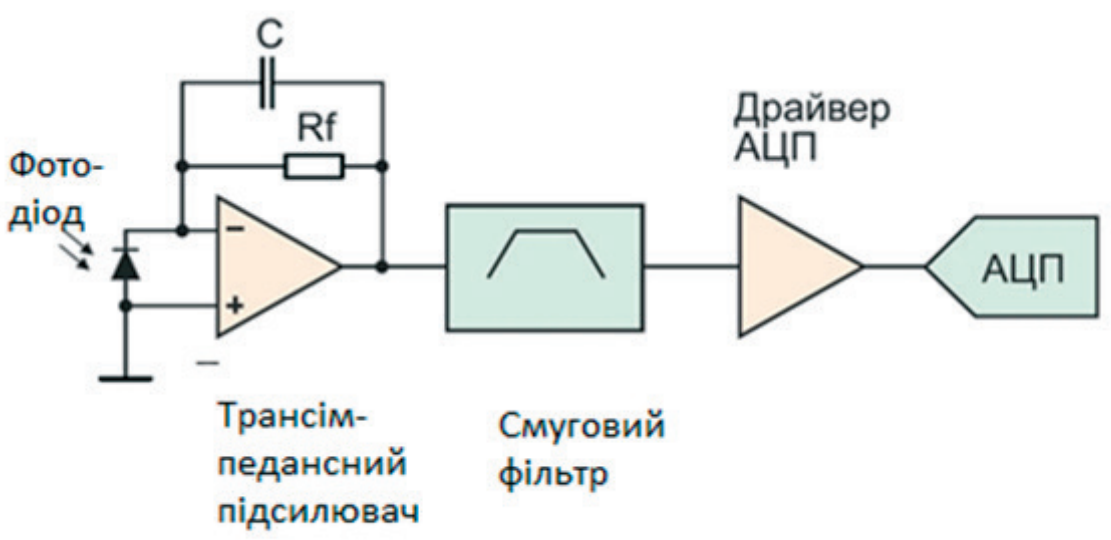

Рис. 2. Функціональна схема фотодетектора 


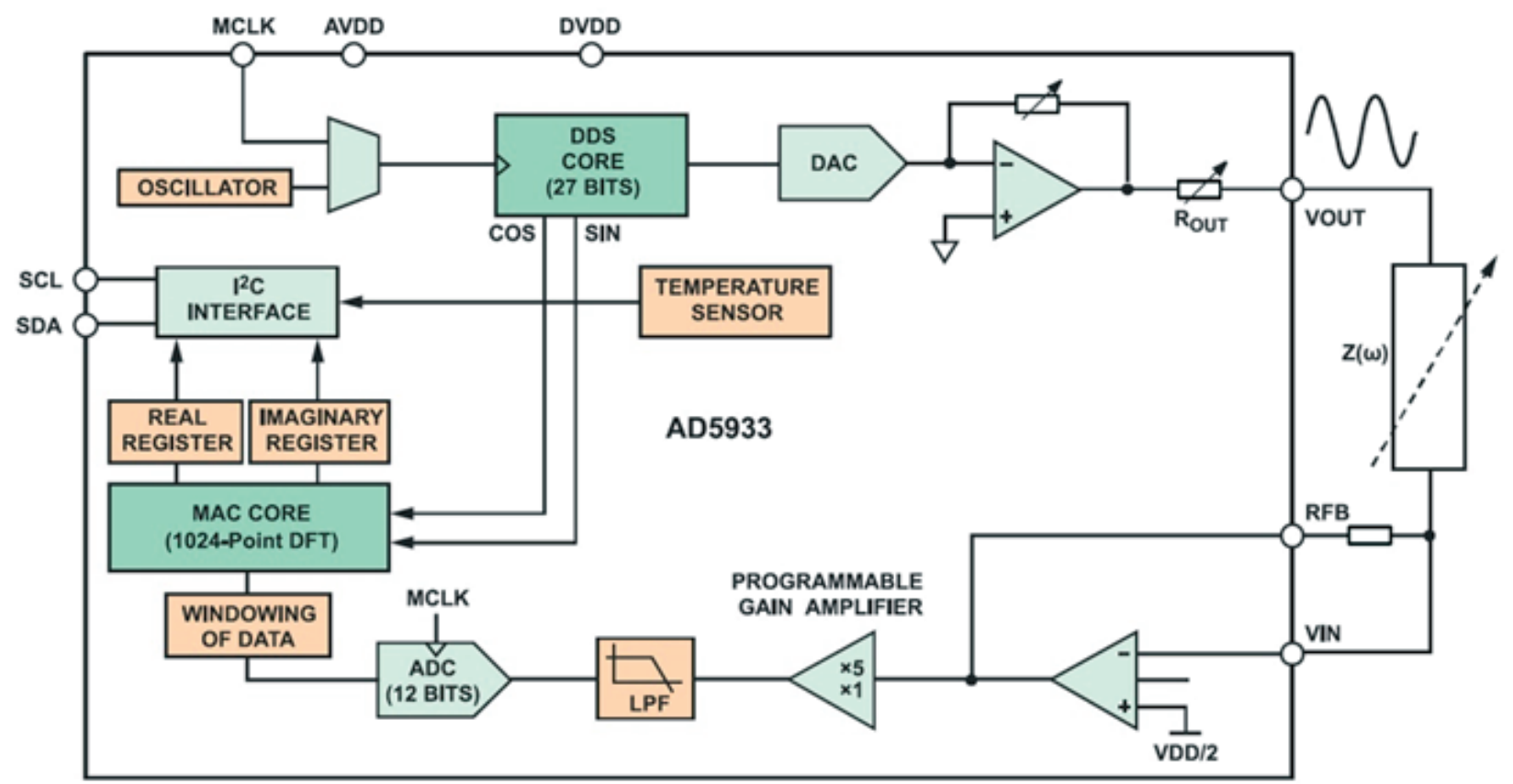

Рис. 3. Функціональна схема імпедансометра

Сенсори включають мініатюрні приймачі для передавання даних про фізіологічні параметри пацієнта на віддалений комп'ютер, в якому експертна система за спеціальною програмою визначає стан людини в експресному режимі. Якщо пацієнту потрібна термінова медична допомога, в медичну службу з вбудованого в одяг навігатора передаються його координати.

На рис. 1 показано сучасні портативні медичні сенсорні пристрої різного призначення. Це тонометри, глюкометри, пульсометри, фотоплетизмографи, оксигемометр, сенсори кардіосигналів, вимірювачі частоти дихання.

Технологічні особливості систем моніторингу. Розглянемо спочатку особливості мікросхем, на основі яких легко можуть бути побудовані ці та інші сенсори фізіологічних параметрів, призначені для вбудовування в одяг.

Фотодетектори широко використовують в портативних медичних приладах і сенсорах (рис. 2), таких як пульсові оксиметри і фотоплетизмографи для вимірювання частоти серцевих скорочень i вмісту кисню в крові, глюкометри для визначення концентрації глюкози в крові, проточної цитометрії та ін. У фотодетекторах світлодіод або матриця світлодіодів генерує імпульс світла певної довжини хвилі, який проходить через шкіру пацієнта, тоді як фотодіод реєструє інтенсивність пропускання відбитого світлового потоку, величина якої пов’язана з вимірюваним фізіологічним параметром.

Прецизійні імпедансометри (рис. 3) призначені для вимірювання часу згортання крові. Вимірюючи опір крові, можна легко встановити момент утворення згустків.

При зніманні сигналів з поверхні шкіри пацієнта необхідно забезпечити високу якість контакту електрода з цією поверхнею. Для цього в медичний електрод вбудовують ємнісний сенсор (рис. 4). Перед зніманням сигналу з електрода відбувається опитування ємнісного сенсора, який сигналізує про якість контакту електрода з поверхнею шкіри в точці знімання сигналів.

Інтегральна мікросхема (IMC) для бездротового кардіографа Холтера розташовується безпосередньо на зворотному боці електрода (рис. 5). Вихідні дані цієї IMC передаються на мобільний телефон або віддалений комп’ютер.

Портативні електрокардіографи, міографи, енцефалографи призначені відповідно для діагностики роботи серця, мускулатури і головного мозку пацієнта. Джерелами інформації для цих приладів $є$ біопотенціали, що знімаються з поверхні тіла пацієнта. Якість сигналів, що знімаються, залежить від параметрів аналогового інтерфейсу. ІМС такого інтерфейсу наведено на рис. 6. 


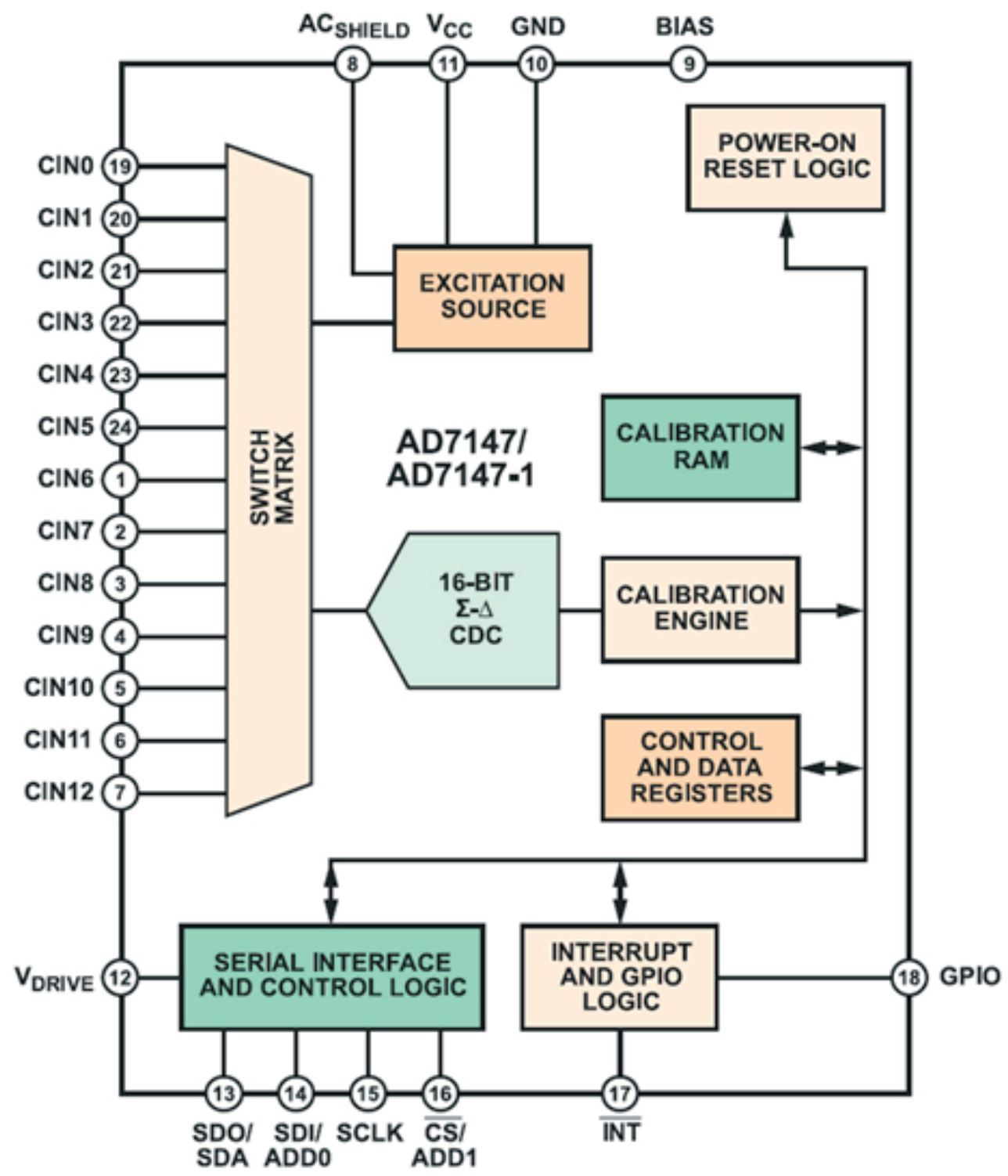

Рис. 4. Функціональна схема ємнісного сенсора

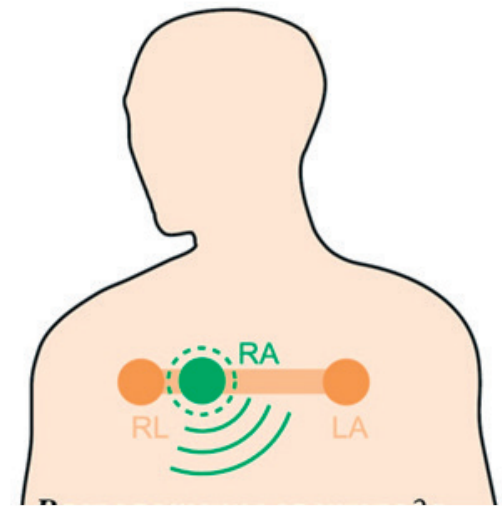

Рис. 5. Кардіоелектрод із мікроелектронним передавачем кардіосигналів. Розташування електрода, суміщеного з монітором Холтера, на тілі пацієнта 


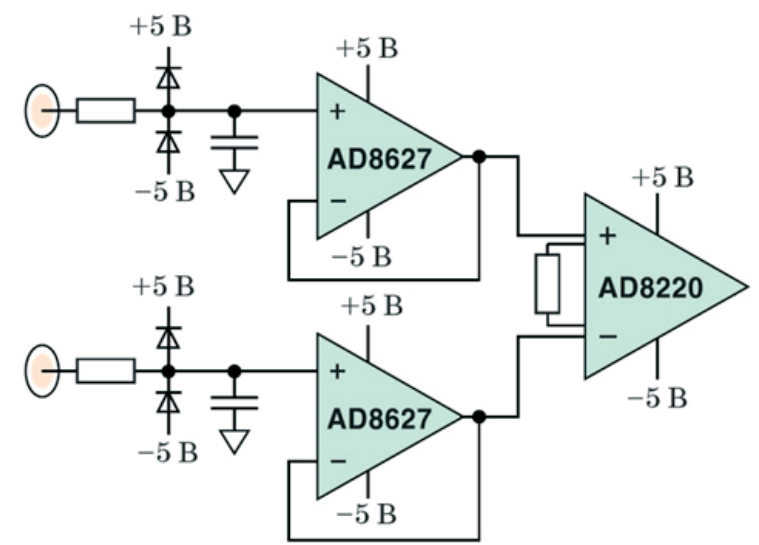

Рис. 6. Аналоговий інтерфейс для знімання біопотенціалів

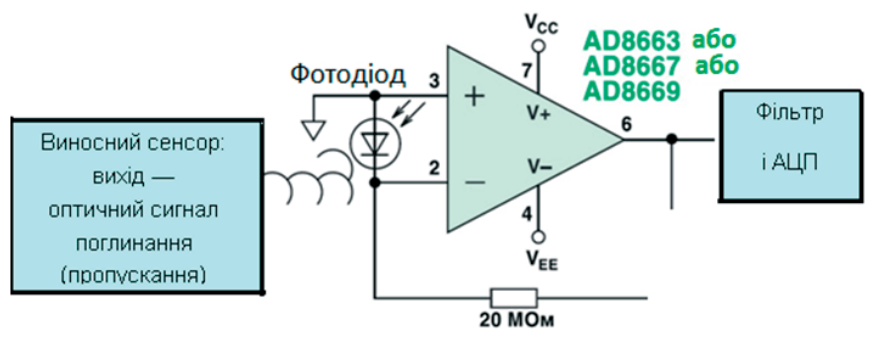

Рис. 7. Схема фотодіодного підсилювача

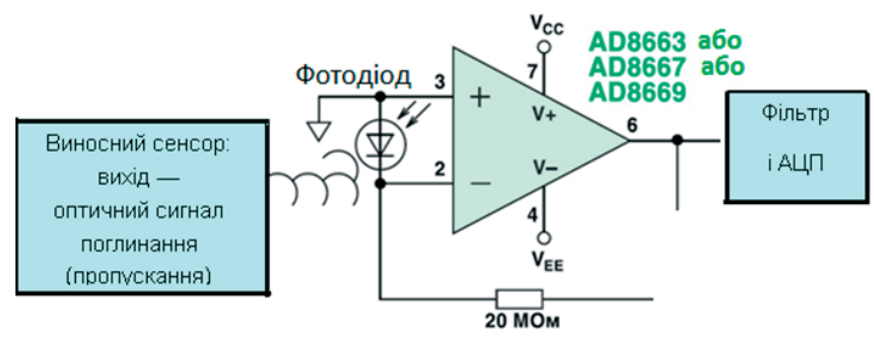

Рис. 8. Портативний вимірювач кров’яного тиску

IMC фотодіодних підсилювачів призначені для вимірювання концентрації кисню в крові пацієнта. Вони використовуються в пульсових оксиметрах. Сенсор може закріплюватися на мочці вуха або на кінчику пальця руки або ноги. Він містить два світлодіода, один з яких випромінює світло в червоній області спектра, а інший — в інфрачервоній. Процентний вміст кисню в крові визначається як відношення інтенсивності пропускання в різних областях спектру. Для зчитування параметра інтенсивності використовується фотодіодний підсилювач, схема якого наведена на рис. 7.

IMC для вимірювання кров'яного тиску застосовується в портативних тонометрах, принцип дії яких полягає в наступному. Сенсор кров’яного тиску встановлюється в манжеті тонометра і фіксує коливання пульсової хвилі. На виході сенсора використовується IMC для фіксації величини верхньої і нижньої межи кров'яного тиску. Схема цієї IMC наведена на рис. 8. Крім того, кров'яний тиск можна перерахувати по швидкості наростання пульсової хвилі фотоплетизмографа, що дозволяє виключити компресор і манжету для вимірювання тиску.

У 2016 році компанія «Analog Devices» представила виготовлену у вигляді наручного годинника комплексну систему стеження за основними життєвими показниками пацієнта GEN II. Годинники містять кілька модулів, розташованих на материнській платі, під керуванням розробленого компанією «Analog Devices» мікроконтролера з ядром 


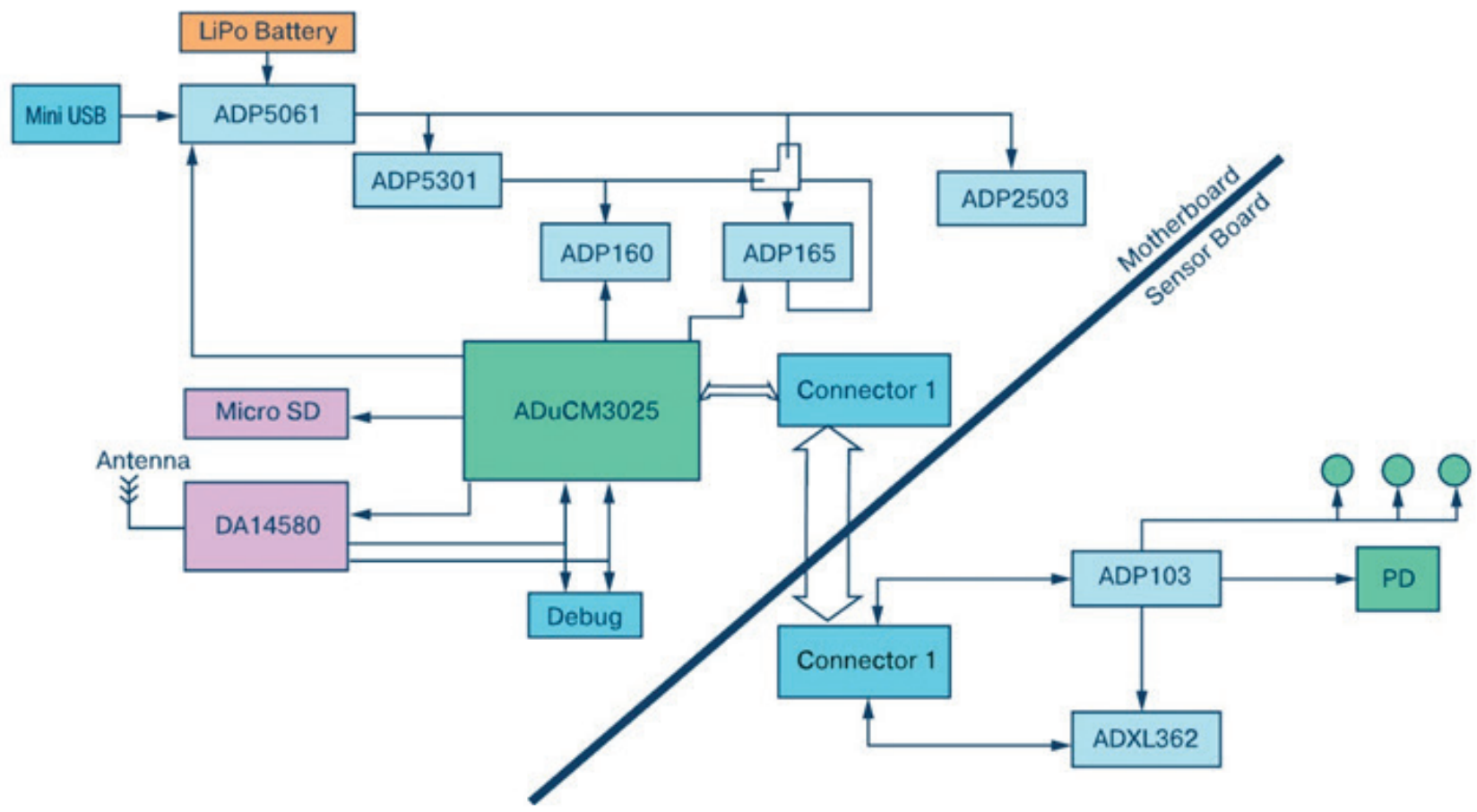

Рис. 9. Структурна схема монітора здоров’я GEN II

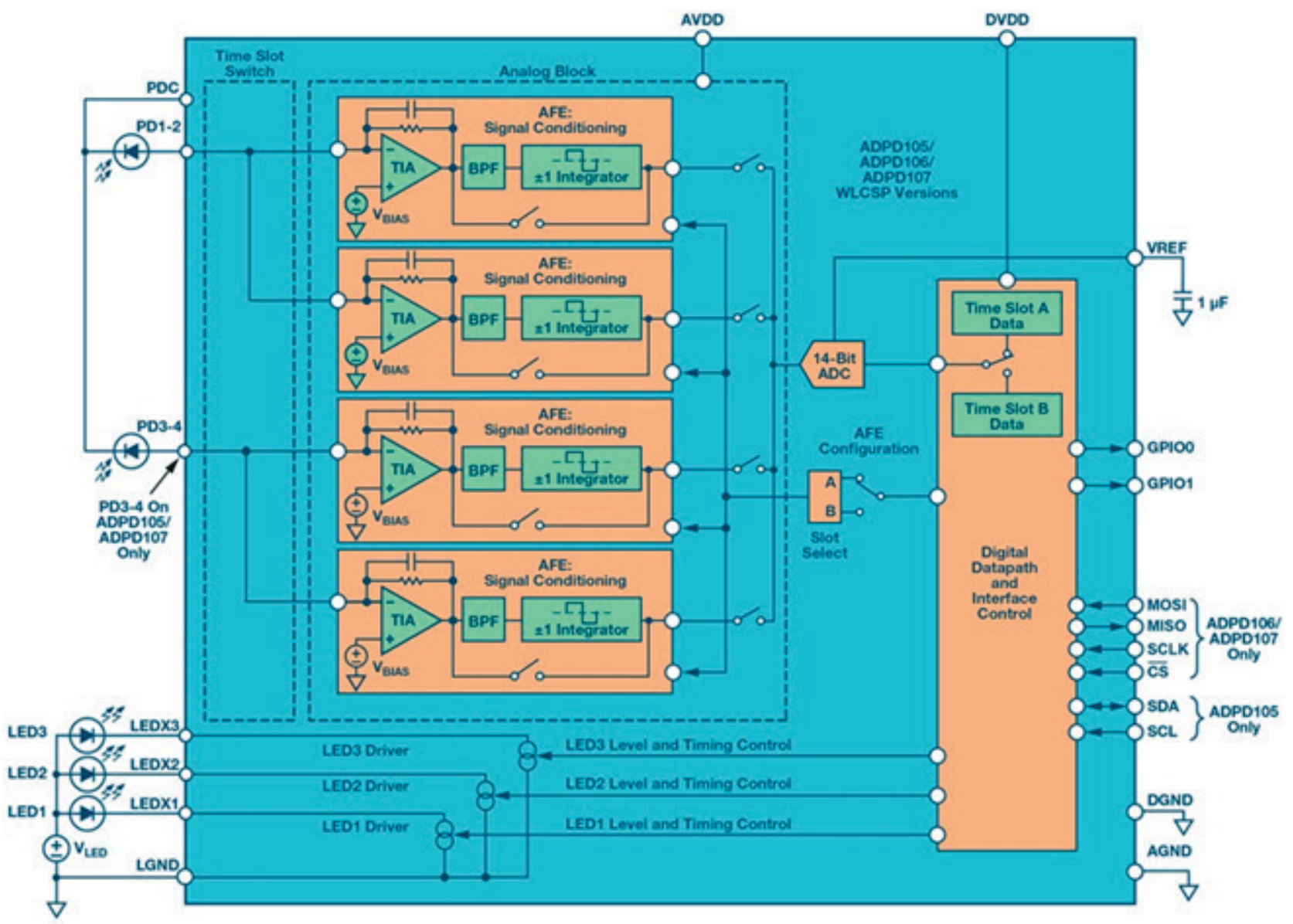

Рис. 10. Структурна схема оптичного блоку ADPD107 


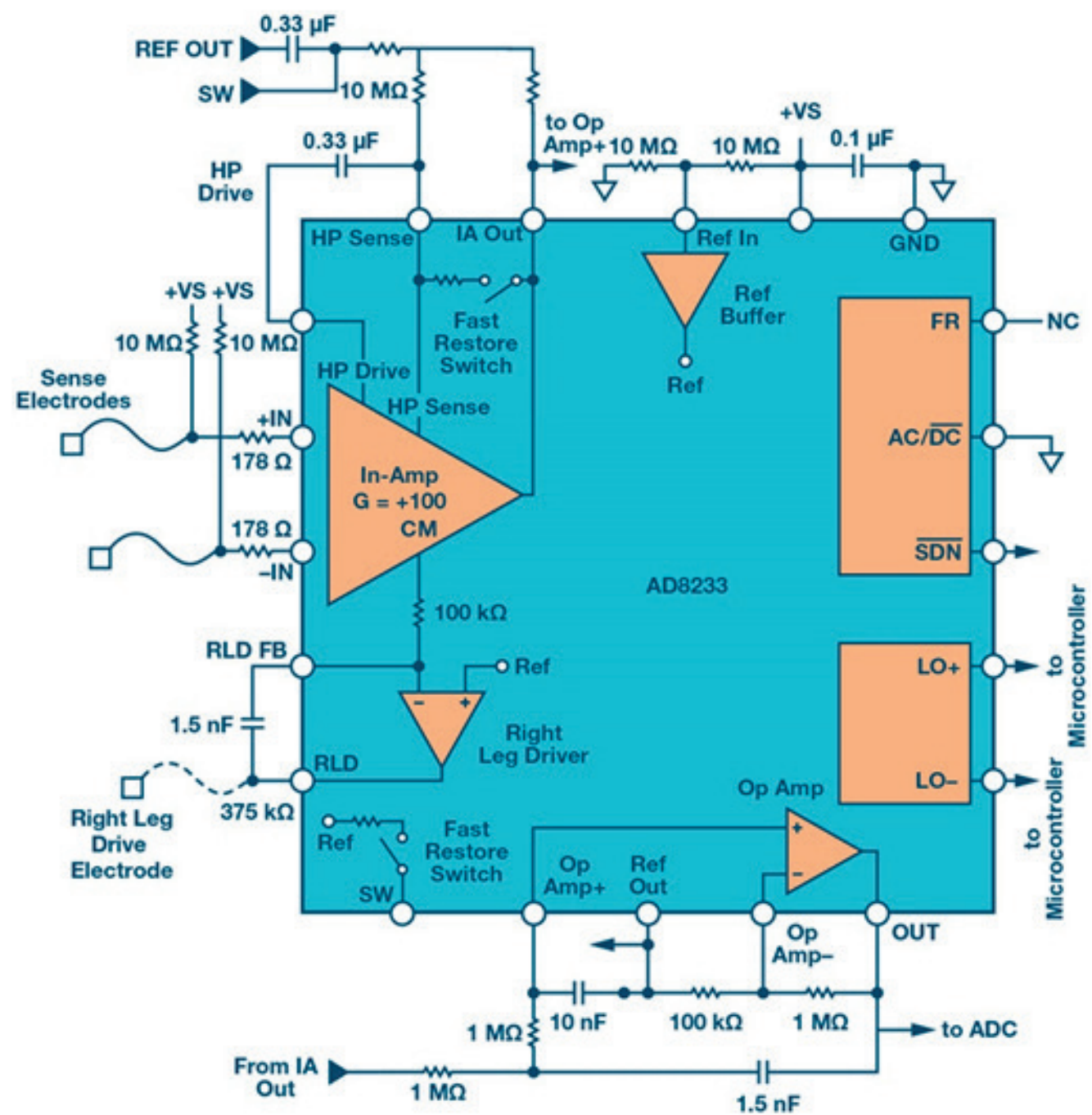

Рис. 11. Структурна схема інтерфейсу AD8233 для кардіосигналів

Cortex-M3 ADuCM302x. У складі годинника $€$ приймач з частотою 2,4 ГГц, фотометричний вузол ADPD103 з трьома зеленими світлодіодами і фотодіодом, а також тривісний акселерометр ADXL362. Фотометричний вузол вимірює частоту серцевих скорочень і рівень насиченості крові киснем. Структурна схема вбудованого в годинник монітора життєво важливих показників здоров'я приведена на рис. 9.

Вбудований у наручний годинник монітор здоров'я, як уже зазначалося, має мале споживання:

- мікроконтролер ADuCM3027 при максимальній тактовій частоті споживання 57 мкА;

- тривісний акселерометр ADXL362 споживає 2 мкA;

- загальне споживання фотометричного вузла на основі мікросхеми ADPD107 не перевищує 563 мKA.
Звідси загальне споживання годинника не перевищує 622 мкА, що гарантує тривалий інтервал часу роботи без підзарядки акумуляторної батареї.

Вбудований у наручний годинник монітор здоров'я GEN II компанії «Analog Devices» призначений для безперервного вимірювання таких життєво важливих показників, як параметри електрокардіограми, частота серцевих скорочень, імпеданс шкірного покриву, стан і ступінь активності пацієнта, а також температура тіла. Відзначимо, що пристрій може, крім того, бути вбудовано в пояс, розташовано на грудній клітці пацієнта. Фотоплетизмограф побудований на базі IMC ADPD107, структурна схема якого наведена на рис. 10.

IMC ADPD107 управляє світлодіодами і за допомогою фотоприймача вимірює сигнали відгуку. Вхідні ланцюги цієї ІМС побудовані на основі трансімпедансних підсилювачів 


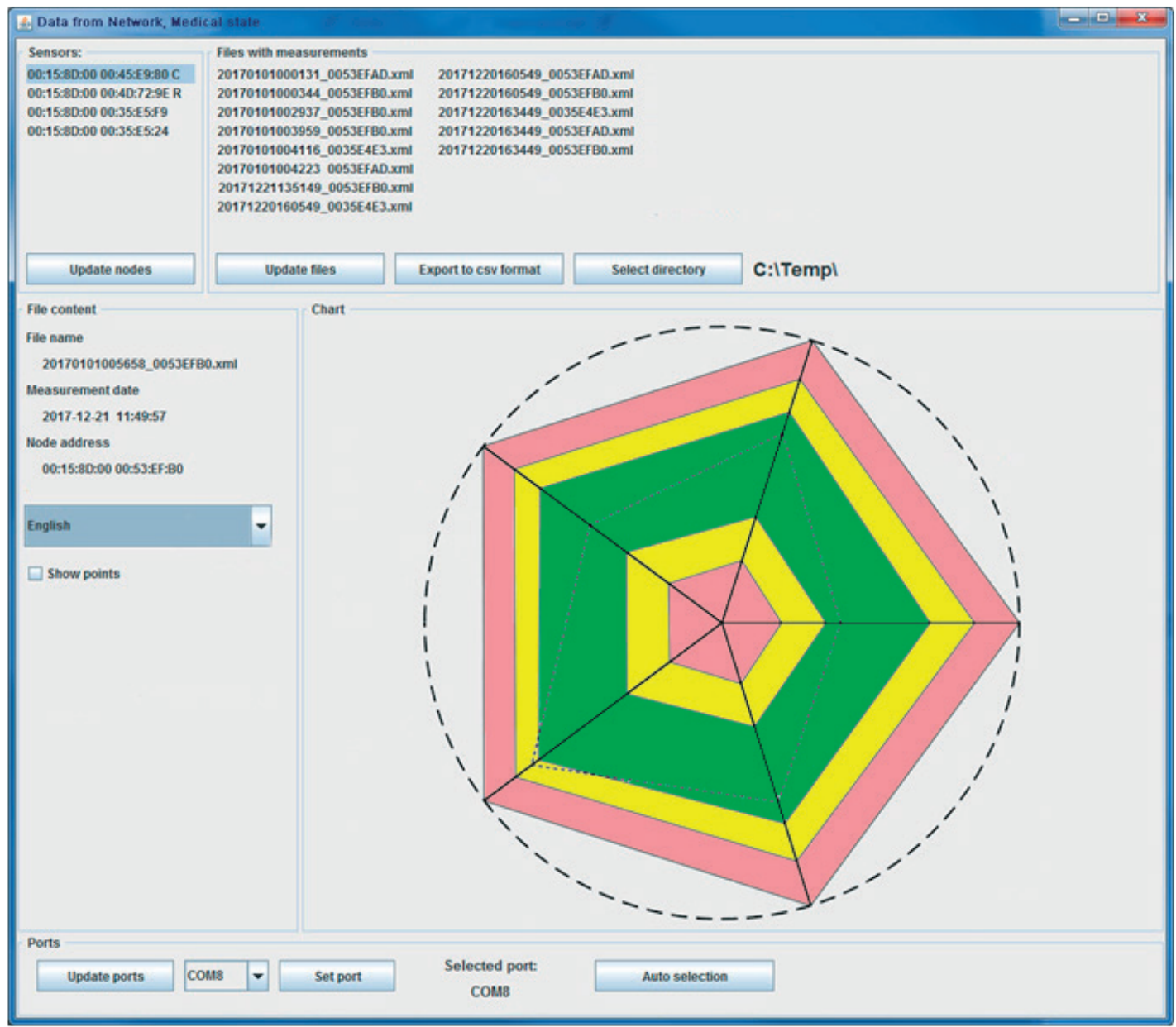

Рис. 12. Вікно прикладної програми з відображенням діаграми

3 чотирикроковим програмованим коефіцієнтом підсилення. Тривалість світлових імпульсів знаходиться в межах 2-3 мкс. АЦП кодує відповідну реакцію в формі імпульсів на виході фотодіодів. Біопотенціали вимірюються за допомогою двох IMC AD8233 (рис. 11), призначених для знімання кардіосигналів з електродів, розташованих на поверхні шкіри пацієнта. Ці IMC підсилюють i фільтрують біопотенціали низького рівня. 3 виходу AD8233 посилені кардіосигнали надходять на вхід 12-розрядного АЦП AD7689. На тильній стороні пристрою GEN II знаходяться два електроди, призначені для вимірювання імпедансу поверхні шкіри. Зміна імпедансу шкіри дає уявлення про емоційне навантаження пацієнта. Подібно кардіосигналам ці сигнали теж кодуються АЦП AD7689. Комплексний імпеданс обчислюється контролером ADuCM3029.

Відзначимо, що всі життєво важливі параметри повинні бути оцінені з урахуванням активності пацієнта, тобто чи знаходиться він в русі чи в спокої.
Для оцінки активності пацієнта в складі GEN II $\epsilon$ тривісний акселерометр ADXL362 з 12-розрядним АЦП. Температура тіла пацієнта вимірюється двома вбудованими в GEN II сенсорами, вихідні сигнали яких кодуються 16-розрядним АЦП.

Новий виріб компанії «Analog Devices» має широкий спектр застосувань. За допомогою GEN II можна вимірювати кров’ яний тиск шляхом обробки пульсової хвилі. При цьому не потрібно застосовувати традиційну манжету. Не викликає сумнівів доцільність застосування монітора здоров'я людьми похилого віку, що дозволяє їм вести активний спосіб життя, постійно перебуваючи при цьому під контролем медичного персоналу. Як було зазначено раніше, обробка фізіологічних параметрів пацієнта виконується за допомогою експертної системи, яка для наочності може бути представлена у вигляді пелюсткової (кругової) діаграми. По осях цієї діаграми (рис. 12) відкладаються виміряні фізіологічні параметри пацієнта. Діаграма може містити кілька зон: зону з нормальними параметрами, кілька 
проміжних зон для параметрів з відхиленнями від нормальних і зону з критичними параметрами. Залежно від того, в якій зоні знаходяться фізіологічні параметри пацієнта, експертної системою приймається рішення про необхідність надання медичної допомоги пацієнту.

При діагностиці захворювання на різних його стадіях ефективне спілкування лікаря з пацієнтом допомагає встановити правильний діагноз, спрогнозувати розвиток захворювання і сприяє швидкому одужанню хворого. Для підтримки спілкування лікаря з пацієнтом (особливо з порушенням мовлення) Інститутом кібернетики імені В. М. Глушкова НАН України та Національною медичною академією післядипломної освіти імені П. Л. Шупика (кафедра медичної інформатики) розроблено спеціальний інтелектуальний медичний комунікатор [2].

Спеціалізоване програмне забезпечення комунікатора складається з ряду підсистем. Програмне забезпечення підтримується базами даних і знань, що містять інформацію про різні захворювання, травми тощо.

Головне вікно комунікатора має п’ять пунктів меню (рис. 13): 1) Потреби; 2) Прохання; 3) Чи турбує біль; 4) Термінова допомога; 5) Клавіатура.

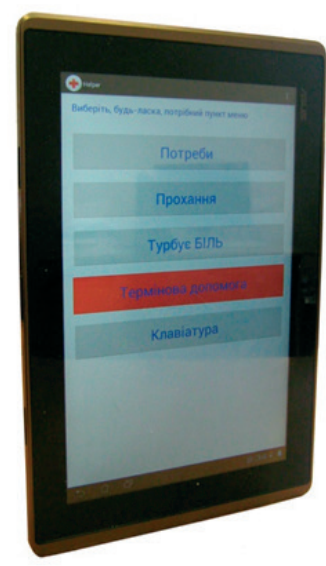

Рис. 13. Головне вікно комунікатора

Пункт меню «Потреби» призначений для виведення на екран списку потреб пацієнта, таких, наприклад, як «хочу їсти», «хочу пити», «хочу спати» та ін.; пункт «Прохання» використовується для виведення на екран прохань пацієнта, наприклад, таких як «говоріть голосніше», «увімкніть телевізор», «відкрийте вікно» та ін.

Пункт меню «Турбує біль» допомагає малорухомому пацієнту з порушенням мовлення точно вказати місце больових відчуттів. Інформація відповідно до цього пункту меню виводиться на екран у графічному вигляді (рис. 14). Паієнт вказує на сенсорному екрані комунікатора ділянку тіла, в якій його турбує біль, причому назва цієї ділянки дублюється звуковою підказкою. Наприклад, це важливо при появі у лежачого пацієнта пролежнів тощо.

Пункт меню комунікатора «Термінова допомога» призначений для термінового виклику пацієнтом лікаря. Виклик може супроводжуватися звуковим сигналом.

Пункт меню комунікатора «Клавіатура» використовується для введення в пристрій додаткових функцій.
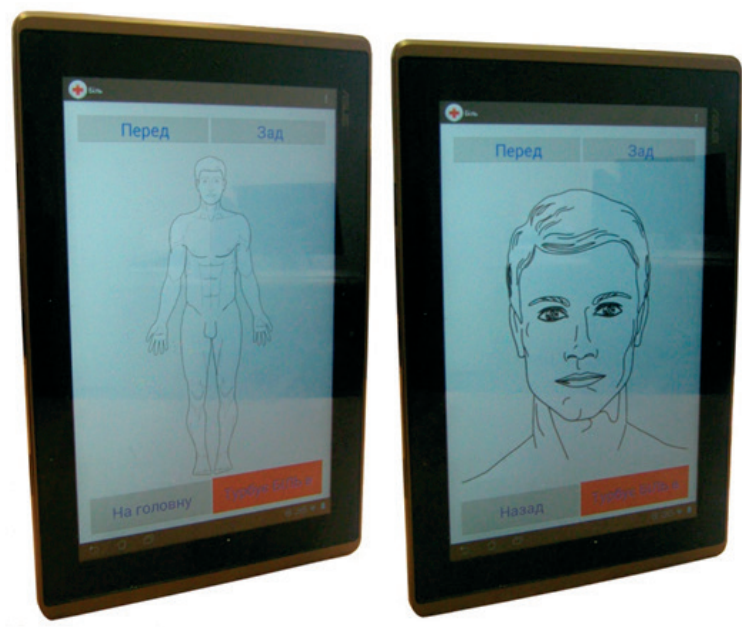

Рис. 14. Вікно комунікатора для вказівки частини тіла, в якій пацієнт відчуває біль

У разі необхідності до інтелектуального комунікатора можуть бути підключені бездротові або дротові медичні датчики, розташовані на тілі пацієнта, такі як датчики кардіосигналів, температури тіла, кров'яного тиску, частоти пульсу та дихання та ін. Всі ці датчики в даний час випускаються компанією «Analog Devices». Завдяки цьому інтелектуальний комунікатор може додатково виконувати функції медичного монітора.

Найважливіша функція комунікатора — підтримка сімейних лікарів при прийнятті рішення, а також спрощення спілкування лікаря і пацієнта. Зрозуміло, що для усунення проблем в спілкуванні лікаря та пацієнта доцільно використовувати формалізовані і стандартизовані моделі та ситуації спілкування, комп’ютеризувати їх для того, щоб усунути помилкове розуміння конкретного «повідомлення» від відправника до одержувача інформації. Тому й очевидним є застосування комунікаторів сімейними лікарями при першому 


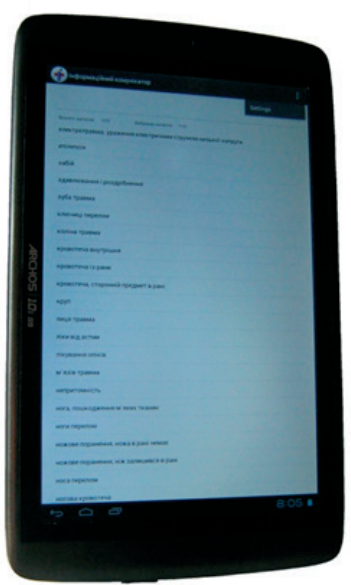

Рис. 15. Перелік захворювань і травм, який підтримується системою пошуку
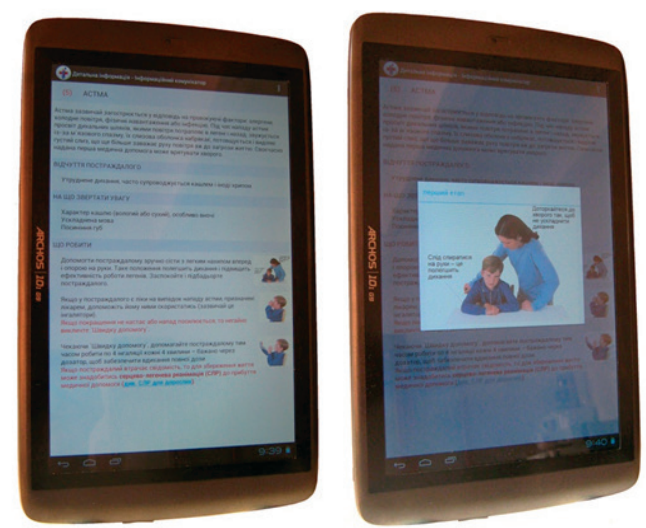

Рис. 16. Детальна інформація про травму або захворювання (з візуальним коментарем)

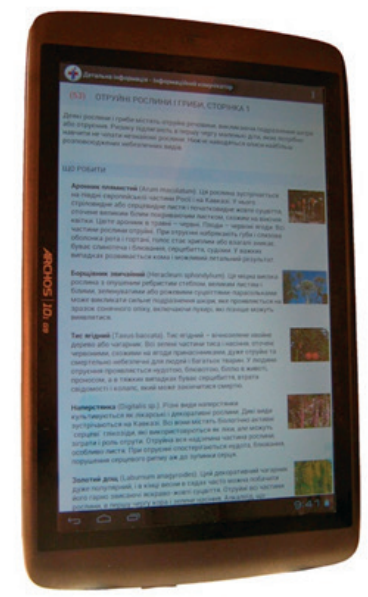

Рис. 17. Довідкова інформація (в нашому прикладі про отруйні рослини та гриби) контакті з пацієнтом для отримання детальної інформації про травму або захворювання і методи догляду та лікування. Це стає особливо актуальним, оскільки сімейні лікарі стикаються з широким спектром захворювань і травм безпосередньо після їх отримання. У таких випадках лікарям часто не вистачає досвіду і знань для оперативного встановлення первинного діагнозу. При цьому обмін інформацією між лікарем і пацієнтом вже передбачає деяке «спотворення» інформації через неправильне або неповне розуміння певної предметної області. Складнощі в комунікації лікар — пацієнт можуть впливати на точність діагнозу та якість лікарської допомоги, а також позначатися на перебігу лікувального процесу. Зауважимо, що в процесі спілкування постає проблема не стільки обміну інформацією, наявності або відсутності в процесі спілкування будь-яких мовних бар’єрів або обмежень, скільки ії адекватного розуміння, тобто проблеми когнітивізму. Це є наслідком суттєвих дисбалансів в напрямку виробництва та застосування знань і стає головною перепоною в поліпшенні діагностики та лікування захворювань. У значній мірі когнітивні труднощі зобов'язані лавині нових медичних фактів. Тому вкрай необхідним $є$ створення та застосування спеціалізованого пристрою для реалізації образного інтелектуального мислення та впровадження сучасних технологій трансляції міждисциплінарних знань.

Розроблений комунікатор усуває такі проблеми шляхом формалізації можливих ситуацій. Для сімейної медицини нами розроблений контент, який об’єднує понад 500 стандартних ситуацій і включає як випадки невідкладної медичної допомоги, так і планові дії медичного персоналу при догляді за пацієнтом (рис. 15-17).

Зупинимося на питаннях використання комунікаторів у практичній медицині більш детально.

Взаємовідносини та спілкування між лікарем і пацієнтом - одна з важливих проблем медицини. У перебігу хвороби та на окремих її стадіях уміння правильного спілкування сприяє вирішенню проблем і труднощів, пов'язаних із встановленням діагнозу та прогнозуванням перебігу хвороби, веде хворого на шляху до скорішого одужання.

Теоретично, інформаційний комунікатор можна використовувати для розв’ язання значної кількості завдань.

1. Для підтримки першого контакту щодо надання детальної інформації про травму або захворювання, відповідні методи догляду та 
лікування при першому огляді пацієнта або постраждалого. Особливо це актуально для сімейних лікарів, які стикаються 3 широким спектром захворювань і травм одразу ж після їх виникнення. В таких випадках часто лікарям не вистачає досвіду та знань для оперативного встановлення вірогідного діагнозу. Тому комунікатор по суті виконує функцію об’ємного довідника для медицини першого контакту. Здійснюється потужний аналіз та підтримка прийняття рішень, які можна отримати на місці огляду хворого чи постраждалого.

Зауважимо, що сімейний лікар не завжди має достатній практичний досвід і, до того ж, не може знати симптоми усіх захворювань або травм та відповідні їм методи догляду або лікування при першому контакті. Використання сучасних інформаційних технологій при першому огляді хворого або постраждалого не тільки лікарями, але і пересічними громадянами дозволить підвищити ефективність та правильність медичних дій при першому контакті. Запропонована програмна підсистема інформаційного комунікатора має бази даних, які містять детальну інформацію про види захворювань та травм, їх опис, відповідні відчуття хворого або постраждалого, на що насамперед слід звертати увагу, детальний опис дій при першій допомозі. Крім того, за результатами аналізу наявних симптомів або відчуттів постраждалого можна діагностувати певні варіанти можливого захворювання або травми.

2. В невідкладній медицині при спілкуванні з пацієнтами, які втратили можливість говорити, або пацієнтами з обмеженими можливостями. В такому випадку засоби і методи альтернативного спілкування допоможуть хворому, у якого виникли тимчасові або постійні проблеми з вербальним мовленням, встановити зв'язок з реальністю.

В комунікаторі можливе віддзеркалення існуючих у сімейній медицині стандартів, протоколів, клінічних настанов. При цьому стандарти та протоколи використовуються лише для створення загального плану ведення пацієнта. Але при подальшому обгрунтуванні діагностичних та лікувальних дій за допомогою клінічних настанов кожен раз здійснюється звірка медичних процедур зі стандартами. При суттєвому відходженні від останніх потрібне додаткове підтвердження від лікаря правильності тактики лікування. Залишаються можливості запам'ятовувати траєкторії ведення хворого, виникнення ускладнень для можливого повторного використання під час корекції рецидивів захворіння в майбутньому.

Важливе значення мають підсистеми, що відображають існуюче нормативно-правове поле та фармацевтичне забезпечення в діяльності сімейного лікаря.

Нарешті, ще одна програмна підсистема інформаційного комунікатора призначена для забезпечення альтернативного спілкування з пацієнтами, які тимчасово або назавжди втратили можливість говорити. Вирішується завдання спеціалізованої медицині, що пов'язане з наданням методів і засобів альтернативного спілкування з людьми, які тимчасово або назавжди втратили можливість говорити, а також повноцінно рухатися в результаті хвороби, аварії або операції. Ідея альтернативного спілкування досить проста - людина з будь-якими порушеннями мовлення потребує необхідності в спілкуванні та можливості впливати на оточення, встановлювати зв'язки з реальністю будь-якими способами. Цей процес встановлення зв'язків за допомогою знаків, додаткових засобів допомагає людині розвивати свої здібності і потреби, навіть якщо у неї виникли тимчасові або постійні проблеми з вербальним мовленням. Таким чином, комунікатори альтернативного спілкування використовуються для розширення комунікативних можливостей у людей, які не говорять або мова яких недостатньо розвинута на даний час.

Основні проблеми подальшого застосування мікроелектронних приладів і технологій. Формально широкі, зовні практично необмежені можливості використання нових інформаційних технологій в дійсності мають істотні обмеження i безліч невирішених проблем.

Серед цієї безлічі, насамперед, називають питання ідентифікації отриманої інформації про стан організму, які $є$ актуальними для більшості методів (за винятком холтерівського і деяких інших записів). Зрозуміло, завдання інтерпретації практично повністю залежить від рішення проблем співвіднесення отриманих даних конкретним статусам організму. При цьому запропоновані більшістю автори підходи, пов'язані з поняттям «норма», далеко не завжди корисні в зв'язку з досить широким діапазоном нормальних величин. Відповідно, другою проблемою у використанні дистанційних методів визначення показників організму є надзвичайно важка (навіть при сучасному розвитку технологій) проблема індивідуалізації в трактуванні отриманої інформації. 
Взагалі кажучи, застосування даних 3 різних пристроїв тісно пов'язане із завданням агрегування даних численних лікувальних установ щодо спостереження за конкретним пацієнтом. При цьому під агрегуванням даних (data aggregation) розуміється забезпечення процесу збору, обробки та подання інформації в остаточному вигляді для формування інтегрального розуміння стану пацієнта, можливі ризики подальшого введення пацієнта, прогнозування подальшого перебігу патологічного процесу і вироблення оптимальної медичної стратегії і тактики лікувальних і профілактичних заходів. Використане визначення дуже близько до дефініції агрегування даних в інформаційних системах охорони здоров'я [3, 5, 6, 8, 10, 12].

Абсолютно зрозуміло, що без коректної діагностики стану пацієнтів скрутними представляються застосування алгоритмів прогнозування, вибору керуючого впливу. Подібна можливість $€$ на нинішньому етапі розвитку медицини лише 3 використанням штучного інтелекту. В іншому випадку число помилок діагностики станів і захворювань, а також у побудові стратегії і тактики лікування патологічного процесу виростає у багато разів [7, 14, 15]. При цьому обробка проводиться методами інтелектуального аналізу даних, головними завданнями яких є пошук функціональних і логічних закономірностей в накопиченій інформації, побудова моделей і правил, які пояснюють патологічний процес і дозволяють прогнозувати розвиток захворювання [1].

Не можна скидати з рахунків і питання стану технічних пристроїв, впливу чинників навколишнього середовища (вологість, температурний режим та ін.).

Все це дозволяє визначити лише обмежені на даний час сфери практичного застосування інформаційних і мікроелектронних пристроїв.

Основне завдання стосується, по суті, чотирьох контингентів пацієнтів: а) пацієнтів у молодому або працездатному віці, але які мають фактори ризику; б) людей, які знаходяться в стані стійкої ремісії основного процесу; в) пацієнтів, які знаходяться в реабілітаційному періоді; г) літніх і старих людей, для яких необхідний моніторинг основних фізіологічних параметрів.

У першому випадку основне завдання вимагає лише здійснення моніторингу виявлених чинників ризику. По-друге, крім моніторингу основних показників, потрібен моніторинг також показників супутніх процесів. В третьому випадку набір показників, які моніторуються, визначається характером патологічного процесу; i, нарешті, в четвертому визначається сутністю патологічного процесу (класу захворювань). Зрозуміло, повинні бути розроблені протоколи (стандарти) станів пацієнтів. Тоді кожному кластеру станів будуть рекомендовані набори датчиків.

Отже, для трьох основних процесів сучасної медичної практики (верифікація стану пацієнтів; ідентифікація наявного стану існуючих кластерів; індивідуалізація підходу для корекції стану пацієнтів) повинні бути і розроблені нові або віднесені до них раніше розроблені пристрої.

У підсумку маємо пари відповідності:

а) кластери станів і відповідні їм набори мобільних пристроїв;

б) відхилення від стаціонарної і запланованої поведінки (динаміки) показників (факторів ризику) та класифікаційні групи динаміки показників (що відповідають варіантам перебігу патологічного процесу);

в) оцінки стану хворих і пристрої швидкої корекції станів пацієнтів.

\section{Висновки.}

1. Сучасні мікроелектронні пристрої, незважаючи на апріорно здавалося б широке застосування, на даний час ще не можуть бути використані в широкому форматі. Сфери їх застосування обмежені практичними випадками, що не вимагають детального знання та передісторії патологічного процесу.

2. На нинішньому етапі розвитку медицини істотне розширення напрямів застосування мікроелектронної техніки може бути забезпечено шляхом спільного її використання зі штучним інтелектом.

\section{Література.}

1. Кречетов Н. Продукты для интеллектуального анализа данных / Н. Кречетов, П. Иванов // ComputerWeek. — 1997. — № 14-15. — С. 32-39.

2. Пат. України на корисну модель № 80490. Спосіб спілкування з людиною, що має мовні та слухові обмеження / Сергієнко І. В., Вороненко О. В., Галелюка І. Б., Романов В. О. — Бюл. № 10 від 27.05.2013.

3. Сахаров А. А. Концепции построения и реализации информационных систем, ориентированных на анализ данных / А. А. Сахаров // СУБД. - 1996. — № 4. - C. 55-70.

4. A $2 \mu \mathrm{w} 100 \mathrm{nV} / \mathrm{rtHz}$ chopper-stabilized instrumentation amplifier for chronic measurement of neural field 
potentials / T. Denison, K. Consoer, W. Santa [et al.] // IEEE Journal of Solid-State Circuits. — 2007. Vol. 42, No. 12. - P. 2934-2945.

5. Adler-Milstein J. America's health IT transformation: translating the promise of electronic health records into better care [Electronic resource] / J. Adler-Milstein ; U.S. Senate Committee on Health, Education, Labor and Pensions. - Mar 17, 2015. - 5 p. — Mode of access: www.help.senate.gov/imo/media/doc/Adler-Milstein. pdf.

6. Adler-Milstein J. Health information exchange among U.S. hospitals: who's in, who's out and why? / J. AdlerMilstein, A. Jha // Healthcare. — 2014. —Vol. 2, No. 1. - P. 26-32.

7. Allen B. Comments from the American College of Radiology. Input submitted to the Committee on Diagnostic Error in Health Care, November 5 and December 29, 2014 / B. Allen, W.T. Thorworth. — Washington, DC, 2014.

8. Appropriate use of the copy and paste functionality in electronic health records [Electronic resource] / AHIMA (American Health Information Management Association). - 2014. - 7 p. — Mode of access : https://bok.ahima.org/PdfView?oid=300306.

9. Cochlear implants: system design, integration, and evaluation / F. G. Zeng, S. Rebscher, W. V. Harrison [et al.] // IEEE Reviews in Biomedical Engineering. 2008. - Vol. 1. - P. 115-142.

10. Data cube: a relational aggregation operator generalizing group-by, cross-tab, and sub-totals / J. Gray, S. Chaudhuri, A. Bosworth [et al.] // Data Mining and Knowledge Discovery. — 1997. — No. 1. — P. 29-53.

11. Demosthenous A. Advances in microelectronics for implantable medical devices [Electronic resource] / A. Demosthenous // Advances in Electronics. Vol. 2014. - 21 p. — Mode of access : https://www. hindawi.com/journals/aelc/2014/981295/.

12. More than half of U.S. hospitals have at least a basic EHR, but stage 2 criteria remain challenging for most / J. Adler-Milstein, C. M. DesRoches, M. F. Furukawa [et al.] // Health Affairs (Millwood). — 2014. — Vol. 33, No. 9. - P. 1664-1671.

13. Ong J. M. The bionic eye: a review / J. M. Ong, L. Da Cruz // Clinical \& Experimental Ophthalmology. 2012. - Vol. 40, No. 1. - P. 6-17.

14. Opening up to precompetitive collaboration / J. S. Altshuler, E. Balogh, A. D. Barker [et al.] // Science Translational Medicine. — 2010. — Vol. 2, No. 52. — P. $52 \mathrm{~cm} 26$.

15. Reducing diagnostic errors through effective communication: harnessing the power of information technology / H. Singh, A. D. Naik, R. Rao, L. A. Petersen // Journal of General Internal Medicine. - 2008. Vol. 23, No. 4. - P. 489-494.

16. Turner J. Microelectronic technology: IEDs spark into life [Electronic resource] / J. Turner // Verdict Medical
Devices. - 2012, 5 August. - Mode of access : https://www.medicaldevice-network.com/features/ featuremicroelectronic-technology-ieds-spark-into-life/.

17. Uranga A. Integrated CMOS amplifier for ENG signal recording / A. Uranga, X. Navarro, N. Barniol // IEEE Transactions on Biomedical Engineering. — 2004. Vol. 51, No. 12. - P. 2188-2194.

18. Vardas P. E. New developments in cardiac pacemakers / P. E. Vardas, E. N. Simantirakis, E. M. Kanoupakis // Circulation. - 2013. - Vol. 127, No. 23. - P. 23432350.

19. Ward C. A short history on pacemakers / C. Ward, S. Henderson, N. H. Metcalfe // International Journal of Cardiology. - 2013. — Vol. 169, No. 4. - P. 244-248.

20. Wilson B. S. Cochlear implants: a remarkable past and a brilliant future / B. S. Wilson, M. F. Dorman // Hearing Research. - 2008. - Vol. 242, No. 1-2. - P. 3-21.

\section{References.}

1. Krechetov, N., \& Ivanov, P. (1997). Produkty dlya intellektual'nogo analiza dannykh [Products for data mining]. Computer Week, 14-15, 32-39. [In Russian].

2. Sergienko, I. V., Voronenko,O. V., Galelyuka, I. B., \& Romanov, V. O. (2013). Patent of Ukraine for utility model № 80490. Sposib spilkuvannya z lyudinoyu, shcho mae movni ta slukhovi obmezhennya [The way to communicate with a person with verbal and auditory limitations]. Bul. No. 10 (27.05.2013). [In Ukrainian].

3. Sakharov, A. A. (1996). Kontseptsii postroeniya i realizatsii informatsionnykh sistem, orientirovannykh na analiz dannykh [Concepts of construction and implementation of information systems focused on data analysis]. SUBD, 4, 55-70. [In Russian].

4. Denison, T., Consoer, K., Santa, W., Avestruz, A. T., Cooley, J., \& Kelly, A. (2007). A $2 \mu \mathrm{w} 100 \mathrm{nV} / \mathrm{rtHz}$ chopper-stabilized instrumentation amplifier for chronic measurement of neural field potentials. IEEE Journal of Solid-State Circuits, 42(12), 2934-2945.

5. Adler-Milstein, J. (2015, Mar 17). America’s health IT transformation: Translating the promise of electronic health records into better care. U.S. Senate Committee on Health, Education, Labor and Pensions. Retrieved from: www.help.senate.gov/imo/media/doc/AdlerMilstein.pdf.

6. Adler-Milstein, J., \& Jha, A. (2014). Health information exchange among U.S. hospitals: who's in, who's out and why? Healthcare, 2(1), 26-32. doi: 10.1016/j. hjdsi.2013.12.005.

7. Allen, B, Thorworth, W. T. (2014). Input submitted to the Committee on Diagnostic Error in Health Care, November 5 and December 29, 2014. Washington.

8. AHIMA (American Health Information Management Association). (2014). Appropriate use of the copy and paste functionality in electronic health records. Retrieved from: www.ahima.org/topics/ehr. 
9. Zeng, F. G., Rebscher, S., Harrison, W. V., Sun, X., \& Feng, H. (2008). Cochlear implants: system design, integration, and evaluation. IEEE Reviews in Biomedical Engineering, 1, 115-142. doi: 10.1109/ RBME.2008.2008250.

10. Gray, J., Chaudhuri, S., Bosworth, A., Layman, A., Reichart, D., Venkatrao, M., Pellow, F., \& Pirahesh, H. (1997). Data cube: a relational aggregation operator generalizing group-by, cross-tab, and sub-totals. Data Mining and Knowledge Discovery, 1, 29-53.

11. Demosthenous, A. (2014). Advances in microelectronics for implantable medical devices. Advances in Electronics, 2014. doi.org/10.1155/2014/981295.

12. Adler-Milstein, J., DesRoches, C. M., Furukawa, M. F., Worzala, C., Charles, D., Kralovec, P., Stalley, S., \& Jha, A. K. (2014). More than half of U.S. hospitals have at least a basic EHR, but stage 2 criteria remain challenging for most. Health Affairs (Millwood), 33(9), 1664-1671. doi: 10.1377/hlthaff.2014.0453.

13. Ong, J. M., \& da Cruz, L. (2012). The bionic eye: a review. Clinical \& Experimental Ophthalmology, 40(1), 6-17. doi: 10.1111/j.1442-9071.2011.02590.x.

14. Altshuler, J. S., Balogh, E., Barker, A. D., Eck, S. L., Friend, S. H., Ginsburg, G. S. ... Wagner, J. A. (2010). Opening up to precompetitive collaboration. Science Translational Medicine, 2(52), 52cm26. doi: 10.1126/ scitranslmed.3001515.
15. Singh, H., Naik, A. D., Rao, R., \& Petersen, L. A. (2008). Reducing diagnostic errors through effective communication: harnessing the power of information technology. Journal of General Internal Medicine, 23(4), 489-494. doi: 10.1007/s11606-007-0393-z.

16. Turner, J. (2012, August 05). Microelectronic technology: IEDs spark into life. Verdict Medical Devices. Retrieved from: https://www.medicaldevice-network.com/ features/featuremicroelectronic-technology-ieds-sparkinto-life/.

17. Uranga, A., Navarro, X., \& Barniol, N. (2004). Integrated CMOS amplifier for ENG signal recording. IEEE Transactions on Biomedical Engineering, 51(12), 2188-2194. doi: 10.1109/TBME.2004.834253.

18. Vardas, P. E., Simantirakis, E. N., \& Kanoupakis, E. M. (2013). New developments in cardiac pacemakers. Circulation, 127(23), 2343-2350. doi: 10.1161/ CIRCULATIONAHA.112.000086.

19. Ward C., Henderson S., \& Metcalfe, N. H. (2013). A short history on pacemakers. International Journal of Cardiology, 169(4), 244-248. doi: 10.1016/j. ijcard.2013.08.093.

20. Wilson, B. S., \& Dorman, M. F. (2008). Cochlear implants: a remarkable past and a brilliant future. Hearing Research, 242(1-2), 3-21. doi: 10.1016/j. heares.2008.06.005. 